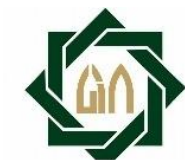

UIN SUNAN AMPEL

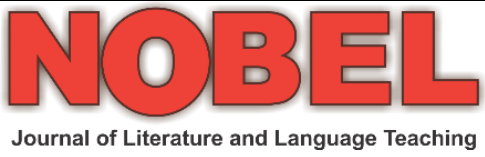

Volume 10, Number 2, September 2019, 163-173

available at http://jurnalfahum.uinsby.ac.id/index.php/nobel/article/view/nomorurut

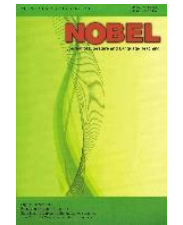

DOI: 10.15642/NOBEL.2019.10.2.163-173

\title{
'LECTURERS' ATTITUDES TOWARDS ENGLISH VARIETIES EXPOSURE IN INDONESIA
}

\author{
Alfan Hariri ${ }^{1 凶}$, Ahmad Munir², Syafiul Anam ${ }^{3}$ \\ Universitas Negeri Surabaya ${ }^{1}$, Jl. Rektorat Unesa, Lidah Wetan, Lakarsantri, Surabaya, East Java 60213 \\ Universitas Negeri Surabaya ${ }^{2}$, Jl. Rektorat Unesa, Lidah Wetan, Lakarsantri, Surabaya, East Java 60213 \\ Universitas Negeri Surabaya ${ }^{3}$, Jl. Rektorat Unesa, Lidah Wetan, Lakarsantri, Surabaya, East Java 60213
}

\begin{tabular}{l}
\hline Article Info \\
\hline Article History: \\
Received February 2019 \\
Accepted July 2019 \\
Published September 2019 \\
\hline Keywords: \\
English Varieties, Attitude, \\
English as International \\
Language (EIL) \\
\hline
\end{tabular}

\begin{abstract}
This study was established from the lack of research of English varieties concept in Indonesia. In this study, the lecturers' attitude toward the English varieties is explored as well as their view about using the English varieties in the classroom. The study used a qualitative research design to seek the participants' attitude toward the varieties. The subjects of the study are ten lecturers of three universities in Surabaya; they are two private and one state university with ten lecturers in total. The researcher used prompt-production to explore in-depth lecturers' attitude. One of the most significant findings to emerge from this study is the differences between the international graduated lecturers and national graduated lecturers in terms of their attitude toward the English varieties. Furthermore, this attitude also influences their perception about teaching the varieties in English language teaching (ELT) classroom.
\end{abstract}




\section{INTRODUCTION}

The widespread of English around the world has triggered the emergence of new English varieties. As a result, in an international context, English learners in the future will seem to interact mostly with non-native English speaker (Jenkins, 2012). From this phenomena, the question of whether the new English varieties are sociolinguistically acceptable as the traditional base of English (American or British) in an international context and how English Language Teaching (ELT) will accommodate the new varieties in teaching-learning process is still being discussed (Jenkins, 2012). One thing that is clear from this issue is that to equip students with the competence to communicate in international context by using English, they must be exposed to these new varieties to understand them.

In fact, along with my experiences of teaching and learning in the Indonesian context, I witness that most of the lecturers rely on the superiority of two English varieties: American and British. Most of the lecturers assume that those two varieties are the only standard English while others such as African English, Singaporean English, Indian English and other Englishes as non-standard (Farrell \& Martin, 2009; Görlach, 1998; Hurtig, 2006; Nickerson, 2005). Thus, in the teaching-learning process, lecturers do not use various English varieties neither teaching various Englishes to the student. As a consequence, students do not know that there are a lot of English varieties other than American and British.

However, in Indonesian ELT context, it is tough to find the research of English varieties both in perspective and practice since the Indonesian lecturers have not moved on yet from the perception that English belongs only to English speaking countries. It is contrary to the fact that in an international context, there have been abundant researches about the issue and practice of the English varieties by the emergence of EIL and ELF. Zacharias (2010) found that Indonesian lecturers believed that English speaking countries as reference or standard of the perfect English. As a consequence, lecturers assumed that the best material to teach English is those made by the native speaker publishers. As an example, in Indonesia, some reputable or international schools still use native centered-based curriculum such as Cambridge as their reference in teaching English. Similarly, Gandana \& Parr (2013) discusses the issue of English varieties applicability through EIL concept in Indonesia. It indicates that lecturers around Asia, including Indonesia, still lack awareness with the issue of English varieties. To this purpose, this study will focus on the Indonesian lecturers' attitude toward English varieties in ELT. 


\section{REVIEW OF LITERATURE}

By the fact that English spread out and is used by the inhabitant peacefully (penetration Pacifique) make it long-lasting even when the colonization is over. According to Crystal (2003) during the colonization, English did not diminish the inhabitant language; instead, it proved its worth. By realizing the value of English, the inhabitant people will automatically learn and use the language to gain the values. Furthermore, the strong hegemony of English speaking country in economy, education, politics, and culture show that English promise beneficial values for the users. In short, by peacefully spread and beneficial values carried, English now is used as lingua franca for international communication.

In fact, eighty percent of English speaker around the world is non-native speaker, which means the student will most probably interact by using English with the different variety of English speaker (Crystal, 2003). Similarly, Kachru (as in Crystal, 2003) classified the English speaker as three circles based on how English is acquired and used in a country.

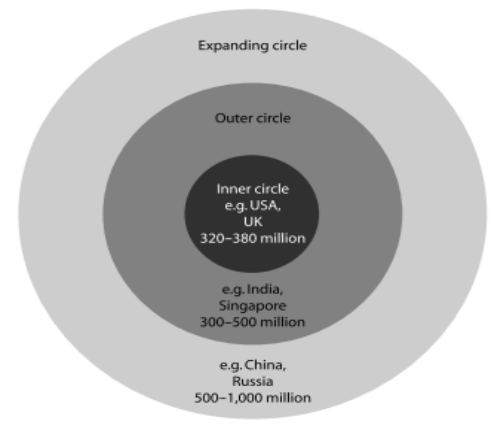

Figure 1.Kachru's three circles (Crystal, 2003, p. 61)

The inner-circle refers to the traditional base of English speaker, where English as the primary language used for communication. For the example, United Kingdom (British), United State (American), Ireland, Australia and so on which the population of English speaker in this circle is approximately 320-380 million (Crystal, 2003). Furthermore, the outer circle refers to the first stage of English spreading around the world commonly through colonialization. The countries included in this type are Australia, India, Malawi, and over fifty countries. The population of this circle is higher than the inner circle of approximately 300500 million speakers (Crystal, 2003). Moreover, the expanding circle consists of the nations which recognize the importance of English as international communication tool and neither have they been colonized by the inner circle country in the past nor they use English for any administrative status (second language). The speakers in this circle are the most massive and 
as its name, it is still growing in terms of the amount since English has been widely recognized and used whether in real or virtual world (Crystal, 2003).

Consequently, with the reality that most English speakers are from the outer circle and the expanding circle, students, especially in Indonesia, will probably interact with these types of speakers in real life. As a matter of fact, in some tourism resorts in Bali, it is reported that Chinese visitors dominated foreign visitors. As a result, when our students come to Bali, they will not only meet with American or British. Instead, they will communicate with the speaker form the expanding circle. In short, English teachers should prepare EFL students with the competence not only to communicate with the inner circle member but also the members of outer and expanding circle.

In response to this issue, there have been some suggestions in ELT to concern about exposing English varieties in ELT. Dewey (2012) language lecturers education in the UK has been primarily concerned with approaches and methods, with relatively little attention given to the subject matter 'English.' English term, in this case, refers to the variety of English occurred around the world. For this reason, recently there have been trends to explore the English varieties in the teaching methodology into the classroom. Dealing with the issue of English varieties, several scholars (Matsuda, 2003; McKay \& Bokhorst-Heng, 2008; Sharifian, 2009) suggest that some significant changes must occur in teachers' and learners' mindset as well as some specific classroom practices.

Furthermore, there have been some attempts by scholars on teaching English varieties in ELT responding toward the issue of exploring the differences and similarities among the varieties. As an example, Jenkin (2007) and Seidlhofer (2011) make tentative suggestions to incorporate some general English varieties principles into ELT when it is required. Similarly, Huang (2008) has attempted to introduce the variety of English in daily usage from the corpus which the goal is to familiarize the different usage of English around the world.

On the other hand, despite the attempts to bring the English varieties into classroom, there have been some flaws in terms of the materials and practices of teaching English varieties. As an example, some researchers also found that the English varieties are not widely exposed in ELT. One of the reasons of teachers' reluctance to teach varieties of English is that they still have strong adherence toward the native speaker which considers as the only correct variety (Farrell \& Martin, 2009; Görlach, 1998; Hurtig, 2006; Nickerson, 2005). Besides, Anne (2005) assumes that the textbooks used do not represent and accommodate the English varieties concept. Similarly, in Indonesia, the textbook which exposes English varieties is limited if any. Thus teachers are reluctant to teach the varieties since the books provided both 
by the government and school do not accommodate the English variety concept (Dewi, 2017; Zacharias, 2003).

\section{METHOD}

Following the characteristic of the qualitative research design which needs in-depth exploration about an object, this research uses the design to seek and explore the lecturers' attitude. Besides, understanding the context of the participants in this research is very crucial since it will influence the participants' attitude toward the issue. In short, this research is qualitative by looking for in-depth understanding and respectively considering the context of the participants in revealing lecturers' attitude about English varieties as well as adopting English varieties as their future target in ELT context.

The subjects of the study of this research are ten lecturers of three higher educations in Surabaya; they are two private and one state university with ten lecturers in total. The promptproduction was used to explore in-depth lecturers' attitude toward the issue. Afterward, the teacher response was transcribed verbatim. Later, the researcher began with open coding which is coding the data for its major categories of information. In this case, a category represents a unit of information composed of events, happenings, and instances (Strauss \& Corbin,1990). During this process, the transcript was classified into a unit based on similar event, examples, opinion, etc. The last step was selective coding where the researcher arranged the correlated categories from the open coding into a model and developed propositions that describe the interrelationship of categories in the model.

\section{RESULTS AND DISCUSSIONS}

After the prompt, the participant showed various responses dealing with the standard or non-standard English of the speakers in the video. Most of the participants are familiar with the English of inner circle speakers in the video. As a matter of fact, they said:

"I guess one of the actors is from UK, but I'm not sure for the other, probably Australian or American. In an academic context, those are the English that we use, but of course, with some adjustment dealing with vocabulary and speed" (participant five).

"I usually hear such of that accent in the movie either in American a British made movie, or in songs. I also teach with these kinds of English to my student in the class" (participant one).

From the sample excerpt, the participants are familiar with the inner circle speakers since they usually watch movie or video with those accents. Similarly, Young and Walsh (2010) found that most Asian teachers are familiar with American English since there are a lot of 
songs and movies from the USA. Furthermore, when they teach, they use the inner circle speaker as a model and reference. This is supported by Young and Walsh'(2010) study which reveals that most of the lecturers use American and British English in ELT classroom. As a result, students only have these two English varieties as the reference of "standard" English.

However, when they saw the outer and expanding circle speakers, they assumed that the speakers are not common and strange. As an example, some of the participants said:

"I know that they speak English, but the English seem strange, there are some words that I'm missing" (participant seven).

"some accents and words are unclear for me, and maybe it is different English" (participant eight).

"I can notify the accent of the speaker that he is an Indian (South Asia) because I used to watch Indian movie so I familiar with the accent even he uses English" (Participant nine).

The participants easily recognize which one is the inner circle English and the outer and expanding circle English. Since they are usually exposed to and use the inner circle English in their teaching and listening to music, so they notify the different English from which they usually listen to and use. The condition echoes what Jenkins (2012) states that the teachers or lecturers in Asia still have strong adherence toward the inner circle English speaker. Furthermore, participant nine notifies the different English from the notable accent of the speaker who has a strong Indian accent in his English.

Besides, some of the participants stated that they were familiar with the outer and expanding circle speaker since they had studied abroad such as in the UK or Australia.

"When I was in Australia, one of my friends is from India, so I used to interact with that accent. At first, it was difficult to understand, but finally, I get used to speaking with them" (participant three).

"In my rent house, there are various students from various countries who stay next to my house. Some of them are from Wales, China, Vietnam, and India. So I used to interact with those varieties" (participant two).

"The UK is now very multicultural; there are a lot of people around the world who live there with different purposes of course. So I used to interact with varieties of speakers in almost all place I visit: classroom, market, mosque" (participant five).

The participant who had studied abroad will be familiar with the different varieties of English because the country where they were studying has heterogeneous society coming from all over the world. As a result, compared to national university graduated participants, dealing with the existence of varieties of English made them more aware of these English varieties. Similarly, Dewi (2017) assumes that the lecturers who graduated from abroad university will have the preference of varieties to be used as the target English since they live with English speakers from different nationalities. 
Furthermore, dealing with the participants' perspective of teaching those varieties in their classroom, difference responses emerge from both national graduated and abroad graduated lecturers. As previously mentioned, the national graduated lecturers are not familiar with the varieties. Consequently, they perceive the varieties other than innercircle variety as non-standard English. For example, some of the participants said:

"Are you kidding me? Exposing students with those uncommon varieties are not academically accepted, I guess because you will never find those varieties in TOEFL, TOEIC and EILTS test or even in textbook or learning materials" (Participant eight).

"I never meet that kind of English (outer and expanding circle) in teaching-learning materials, so why we should teach students English which is not standard and widely used in an international context" (participant nine).

"Are we going to mislead our students? They (English outer and expanding circle speakers) speak ungrammatical English and inappropriate intonation and pronunciation. I think it will be better to teach students with American and British. With these two (American and British) main varieties, I do believe that students will be able to communicate with all English speakers around the world" (participant ten).

The national graduated lecturers assume that teaching English varieties is not urgent since the "standard" variety will be adequate to make the student be able to communicate in an international context. Furthermore, they assume that the varieties other than American and British were not found in teaching materials and some English proficiency tests such as TOEFL, TOEIC, and EILTS. In the same way, Young \& Walsh'(2010) study about lecturers' attitude toward the exposure of English varieties in ELT revealed that some lecturers in Asia assume English varieties as broken and non-standard English. Similarly, Jenkin (2012) conducted a study about lecturers' attitude toward English varieties exposure in the classroom. He found an interesting fact dealing with the preference of American and British English for the lecturers, where their confidence of English skill and mastery is relying on how good they can be American and British-like speaker.

Besides, Young \& Walsh (2010) found that most of the teachers use only two English varieties (American and British). As a consequence, in teaching-learning process lecturers do not use various English varieties neither teaching various English varieties to the students. Thus, the students do not know that there are a lot of English varieties other than American and British.

As a result, students who are only exposed to one or two varieties may think that those are the only correct and acceptable varieties. The condition is supported by Alatis (1995), Ur (2010) and Bauer (2002) who reveal that with only one or two varieties introduced to the students, they may think that the speaker of different English varieties to be claimed as bad 
English. Similarly, some researchers assume that it is not necessary for L2 students to acquire native-speaker norms to be considered competent in English (Alsagoff, Mckay, Hu, \& Renandya, 2012; Jenkins, 2012; Kirkpatrick, 2006).

Zacharias (2010) found that the Indonesian lecturers believed that English speaking country is the reference or standard of perfect English. As a consequence, the lecturers assumed that the best material to teach English is the materials made by the native speaker publishers. As an example, in Indonesia, some reputable or international schools still use native centered based curriculum such as Cambridge as their reference in teaching English. Similarly, Gandana \& Parr (2013) discuss the issue of English varieties applicability through EIL concept in Indonesia. It indicates that lecturers around Asia including Indonesia still lack awareness with the issue of English varieties

On the other hand, the international graduated lecturers are more aware of the English varieties around the world since they have experienced the interaction either directly or indirectly in their university with the speakers with English varieties.

"I have a unique experience of how I am aware of English varieties. When I make listening materials in one of my course assignment, my lecturer told me that my listening, not authentic since it contained only one variety of speakers. In fact, there are various speakers in the UK, and they have their own English varieties. So, she suggested that I add the materials" (participant four).

"by the fact that I experience and know the different English varieties, sometimes I question myself which English I should use to teach my students. Recently, I have been reading the theory of world Englishes, and I think it is very logic that nonnative English speakers have greater amount than native speakers. For this reason, it is reasonable to prepare students with those varieties" (participant two).

"When I was in Australia, I had many friends from New Zealand, yes they speak English, but their English is a bit different, there are some words that you might not understand since they pronounce differently from the UK, British or even Australian English. For this reason, it is important to introduce the English varieties to the students" (participant four).

"I am really excited about teaching English varieties to my students because it is still uncommon issues and perspective in Indonesia. I really want to see how my students' reaction is dealing with this issue" (participant three).

The participants experience the English varieties since they were living abroad with different varieties of speakers communicating with them. With these experiences, the participants are aware of the importance of introducing English varieties around the world. Dewi (2017) confirmed that the lecturers who had studied abroad had experienced the English varieties since they interact with the different nationalities with different varieties of English as well. 
In addition, the participants feel it is essential to teach students English varieties to make them aware that English is not only American and British. This intention comes because they experienced as students when the lecturers only focus on one or two varieties. Similarly, Young \& Walsh (2010) revealed that most of the teachers or lecturers in Asia use American English as the target language in their teaching. Being aware of the varieties of English, Sung (2016) suggests that it is also crucial that lecturers help empower learners to make choices about the language they use so that they can become fully competent speakers of English who are capable of presenting themselves in whatever way they would like.

However, in spite of their positive attitude toward the English varieties, studies have revealed that lecturers find it difficult to implement the English varieties in the teachinglearning process. There are two fundamental reasons underlie this condition; they are the availability of materials and the government's rule in language education. Dewi (2017) revealed that the materials which expose varieties of English are limited if any. Similarly, Young and Walsh (2010) stated that American-based publisher has more domination in providing English learning material. The fact is supported by Anne's (2005) study which reveals that the textbook used did not represent and accommodate the English varieties concept. In addition, the educational ministry in Asia still demands the teachers to use American and British as target English (Görlach, 1998). As a result, teacher has no power to choose the material and decide which varieties to expose in their ELT classroom.

\section{CONCLUSION}

The following points emerged from the present investigation: 1) there are differences between the international graduated lecturers and national graduated lecturers in terms of their attitude toward the English varieties. The international graduated lecturers have awareness about the English varieties since they are exposed to those varieties when they stayed abroad. On the other hand, the national graduated lecturers tend to rely on the inner circle English as their reference in their teaching. 2) Furthermore, this attitude also influences their perception about teaching the varieties in English language teaching (ELT) classroom. The national graduated lecturers have strong adherence toward inner circle English varieties in ELT classroom. On the contrary, the international graduated lecturers are more open-minded to accommodate the different varieties of English for their students.

\section{REFERENCES}

Alatis, J. E. (1995). Linguistics and the education of language teachers. Washington, D.C.: Georgetown University Press. 
Alsagoff, L., Mckay, S. L., Hu, G., \& Renandya, W. A. (2012). Principles and practices for teaching English as an international language ( $1^{\text {st }} \mathrm{ed}$.) London: Routledge.

Anne, K. (2005). Accents of English as a lingua franca: A study of Finish textbooks. International Journal of Applied Linguistics, 21(April), 94.

Bauer, L. (2002). An introduction to international varieties of English. Edinburgh: Edinburgh University Press Ltd.

Crystal, D. (2003). English as a global language. (2 ${ }^{\text {nd }}$ ed.) Cambridge: Cambridge University Press.

Dewey, M. (2012). Towards a post-normative approach: learning the pedagogy of ELF. Journal of English as a Lingua Franca, 1, 141-170. https://doi.org/DOI 10.1515/jelf2012-0007

Dewi, A. (2017). The English ( es ) to teach after study and life in Australia: a study of Indonesian English language educators. Asian Englishes, 8678(July), 1-20. https://doi.org/10.1080/13488678.2017.1279762

Farrell, T. S. C., \& Martin, S. (2009). To teach standard English or world Englishes? English Teaching Forum.

Gandana, I., \& Parr, G. (2013). Professional identity, curriculum and teaching intercultural communication: an Indonesian case study. Language, Culture and Curriculum, 26(3), 229 - 246. https://doi.org/10.1080/07908318.2013.833620

Görlach, M. (1998). Varieties of English world-wide: where we stand. Links \& Letters, (September 1997), 13-36. Retrieved from http://ddd.uab.es/pub/linksandletters/11337397n5p13.pdf

Huang, L.-S. (2008). Using guided corpus-aided discovery to generate active learning. English Teaching Forum, 4, 20-27.

Hurtig, M. (2006). Varieties of English in the Swedish classroom. Karlstads universitet.

Jenkins, J. (2012). English as a lingua franca from the classroom to the classroom. ELT Journal, 66(4), 486-494. https://doi.org/10.1093/elt/ccs040

Kirkpatrick, A. (2006). Asian englishes: implications for english language teaching. Asian Englishes, 9(2), 4-19. https://doi.org/10.1080/13488678.2006.10801186

Matsuda, A. (2003). Incorporating world Englishes in teaching English as an international language. TESOL Quarterly, 37(4), 719-729. https://doi.org/10.2307/3588220

McKay, S.L., \&Bokhorst-Heng, W.D. (2008). International English in its sociolinguistic contexts: Towards a socially sensitive EIL pedagogy. New York, London, England: Routledge.

Nickerson, C. (2005). English as a lingua franca in international business contexts. English for Specific Purposes, 24(4 SPEC. ISS.), 367-380. https://doi.org/10.1016/j.esp.2005.02.001

Seidlhofer, B. (2011). Conceptualizing 'English' for a multilingual Europe. in A. D. Houwer and A. Wilton (Eds.), English in Europe today: Sociocultural and educational perspectives (133-146). Amsterdam/Philadelphia: John Benjamins Publishing Company

Sharifian, F. (2009).English as an international language: Perspectives and pedagogical issues. Bristol, England: Multilingual Matters. 
Strauss, A. \& Corbin, J. (1990). Basics of qualitative research. Gender Open Repositorium. https://doi.org/10.5072/genderopen-develop-7

Sung, C. C. M. (2016). Exposure to multiple accents of English in the English Language Teaching classroom: from second language learners' perspectives. Innovation in Language Learning and Teaching, 10(3), 190-205. https://doi.org/10.1080/17501229.2014.936869

Ur, P. (2010). English as a lingua franca: A teacher's perspective. Cadernos de Letras, 27, $85-92$.

Retrieved

from

http://www.letras.ufrj.br/anglo_germanicas/cadernos/numeros/122010/textos/cl30122010 Openny.pdf

Young, T. J., \& Walsh, S. (2010). Which English? Whose English? An investigation of "nonnative" teachers' beliefs about target varieties. Language, Culture and Curriculum, 23(2), 123-137. https://doi.org/10.1080/07908311003797627

Zacharias, N. T. (2003). A survey of tertiary teachers beliefs about English Language Teaching in Indonesia with regard to the role of English as a global language. Assumption University of Thailand.

Zacharias, T. (2010). The teacher identity construction of 12 asian ES teachers in TESOL graduate programs *, 7(2), 177-197. 